\title{
A Vitamin D Analogue (EB1089) Inhibits Parathyroid Hormone-related Peptide Production and Prevents the Development of Malignancy-associated Hypercalcemia In Vivo
}

\author{
Mahmudul Haq, ${ }^{*}$ Richard Kremer, ${ }^{\star}$ David Goltzman, ${ }^{\star \star}$ and Shafaat A. Rabbani* \\ Departments of ${ }^{*}$ Medicine and ${ }^{\ddagger}$ Physiology, McGill University; and Calcium Research Laboratory, \\ Royal Victoria Hospital, Montreal, Canada H3A 1 A1
}

\begin{abstract}
We have examined the effects of 1,25 dihydroxyvitamin $D_{3}$ $\left(1,25[\mathrm{OH}]_{2} \mathrm{D}_{3}\right)$ and a low calcemic analogue EB1089 on parathyroid hormone-related peptide (PTHRP) production and on the development of hypercalcemia in Fischer rats implanted with the Leydig cell tumor $\mathrm{H}-500$. Leydig cell tumors were implanted subcutaneously into male Fischer rats, which received constant infusions intraperitoneally of either $1,25(\mathrm{OH})_{2} \mathrm{D}_{3}$ (50-200 pmol/24 h), EB1089 (50-400 pmol/24 h), or vehicle for up to 4 wk. A control group of animals received similar infusions without tumor implantation. Plasma calcium, plasma levels of immunoreactive iPTHRP, and tumor PTHRP mRNA levels were determined as well as tumor size, animal body weight, and animal survival time. Non-tumor-bearing animals receiving $>50 \mathrm{pmol} / 24 \mathrm{~h}$ of $1,25(\mathrm{OH})_{2} \mathrm{D}_{3}$ became hypercalcemic, whereas no significant change in plasma calcium was observed in animals receiving $\leq \mathbf{2 0 0} \mathrm{pmol} / \mathbf{2 4} \mathrm{h}$ of EB1089. Tumor-bearing animals receiving vehicle alone or $>50 \mathrm{pmol} / 24 \mathrm{~h}$ of $1,25(\mathrm{OH})_{2} \mathrm{D}_{3}$ became severely hypercalcemic within $15 \mathrm{~d}$. However, animals treated with low dose $1,25(\mathrm{OH})_{2} \mathrm{D}_{3}$ and all doses of EB1089 maintained near-normal or normal levels of plasma calcium for up to $4 \mathrm{wk}$. Additionally, reduced levels of tumor PTHRP mRNA and of plasma iPTHRP were observed compared with controls in both vitamin D- and EB1089-treated rats. Infusion of $50 \mathrm{pmol} / 24 \mathrm{~h}$ of $1,25(\mathrm{OH})_{2} \mathrm{D}_{3}$ and $200 \mathrm{pmol} /$ $24 \mathrm{~h}$ of EB1089 significantly reduced tumor volume by the end of experiment. The analogue but not $1,25(\mathrm{OH})_{2} \mathrm{D}_{3}$ substantially prolonged survival time in tumor-bearing animals with longer survival achieved at the highest dose, $400 \mathrm{pmol} / 24 \mathrm{~h}$, of EB1089. These studies demonstrate that $1,25(\mathrm{OH})_{2} \mathrm{D}_{3}$ and a low calcemic vitamin $D$ analogue are potent inhibitors of PTHRP production in vivo. Low calcemic analogues may therefore represent important alternative therapy for malignancyassociated hypercalcemia. (J. Clin. Invest. 1993. 91:24162422.) Key words: vitamin $D \cdot$ parathyroid hormone-related peptide • malignancy $\bullet$ hypercalcemia $\bullet$ Leydig cell tumor
\end{abstract}

\section{Introduction}

Hypercalcemia is a common complication of human malignancy and may produce considerable morbidity and mortality.

Address correspondence to Shafaat A. Rabbani, M.D., Calcium Research Laboratory, Royal Victoria Hospital, Room H4-72, 687 Pine Avenue West, Montreal, Quebec H3A 1A1, Canada.

Received for publication 17 November 1992 and in revised form 6 January 1993.

J. Clin. Invest.

(c) The American Society for Clinical Investigation, Inc.

0021-9738/93/06/2416/07 \$2.00

Volume 91, June 1993, 2416-2422
Parathyroid hormone-related peptide (PTHRP) ${ }^{1}$ is a recently described entity that has been shown to be a pathogenetic mediator of humoral hypercalcemia of malignancy (1-6). Hypercalcemia may also occur in association with a number of animal neoplasms. Among the best characterized of the animal models, and one which closely mimics the human syndrome, is the male Fischer rat implanted with the Rice 500 Leydig cell tumor $(7,8)$. PTHRP is well documented to cause the hypercalcemia associated with this tumor $(9,10)$. Currently, the mainstays of therapy for malignancy-associated hypercalcemia are agents that inhibit skeletal calcium mobilization, such as bisphosphonates and calcitonin, or agents that enhance renal calcium clearance, such as loop diuretics. However, PTHRP is known to cause hypercalcemia by its action on both bone and kidney. Consequently, a therapeutic strategy aimed at inhibiting PTHRP production and thereby neutralizing both mechanisms simultaneously might be a useful addition to our antihypercalcemic armamentarium. To date, no such strategy has been reported.

PTHRP expression has been shown to be regulated by multiple factors in a variety of human cell lines in vitro, including rat Leydig cells grown in culture. We have recently shown that in cultured Leydig cells several steroidal factors such as testosterone and dexamethasone inhibit PTHRP gene expression and secretion. The seco-steroid 1,25 dihydroxyvitamin $D_{3}$ $\left(1,25[\mathrm{OH}]_{2} \mathrm{D}_{3}\right)$ is also inhibitory of PTHRP production in vitro both in this tumor and in other normal and malignant cell types (11-14). Nevertheless the in vivo efficacy of this substance is unknown. In the present study we have therefore examined the capacity of $1,25(\mathrm{OH})_{2} \mathrm{D}_{3}$ and of a low calcemic vitamin D analogue, EB1089, to inhibit PTHRP production by the Rice 500 Leydig cell tumor in vivo and to prevent the development of hypercalcemia. Effects on body weight and tumor volume were also examined and the effect on animal survival time was assessed.

\section{Methods}

Vitamin D and analogue. 1,25-(OH) $)_{2} \mathrm{D}_{3}$ was a generous gift of Dr. $\mathrm{M}$. Uskokovic of Roche Pharmaceuticals (Nutley, NJ). EB1089 is an analogue of $1,25(\mathrm{OH})_{2} \mathrm{D}_{3}$ which was kindly provided by Leo Pharmaceuticals (Ballerup, Denmark) (15).

Animal protocols. Male Fischer 344 rats (Charles River Breeding Laboratories, Inc., Wilmington, MA), weighing 200-220 g (10 wk of age), were used in all studies. Animals were housed individually and maintained on tap water ad lib. and standard rodent chow (rat chow

1. Abbreviations used in this paper: $\mathrm{PPTHRP}$, immunoreactive parathyroid hormone-related peptide; $1,25(\mathrm{OH})_{2} \mathrm{D}_{3}, 1,25$ dihydroxyvitamin $\mathrm{D}_{3}$; PTHRP, parathyroid hormone-related peptide. 
5012; Ralston-Purina Canada, Inc., Lasalle, Quebec, Canada) containing $1 \%$ calcium and $0.74 \%$ phosphorus (16). The Rice-500 Leydig cell tumor was obtained from the National Cancer Institute Breast Cancer Task Force Bank (EEG Mason Research Institute, Worcester, MA). The tumor was minced in normal saline to give a suspension of one part of tumor to one part of saline. Tumor suspension $(0.2 \mathrm{ml})$ was then injected into the right flank of each test animal. Control animals were weight matched and maintained under identical conditions (9).

To examine the effect of $1,25(\mathrm{OH})_{2} \mathrm{D}_{3}$ and EB1089 on tumor-bearing animals, osmotic minipumps (model 2ML4 Alzet; Alza Corporation, Palo Alto, CA) were implanted intraperitoneally under light ether anesthesia. Each minipump contained either $1,25(\mathrm{OH})_{2} \mathrm{D}_{3}$ or $\mathrm{EB} 1089$ dissolved in $1 \mathrm{ml}$ of propylene glycol, $200 \mu \mathrm{l}$ of ethanol, and $800 \mu \mathrm{l}$ of saline to deliver a continuous dose of the compound for up to $4 \mathrm{wk}$ at a delivery rate of $2.5 \mu \mathrm{l} / \mathrm{h}$ (17). On the day of tumor implantation all tumor-bearing animals also received a loading dose equivalent to one daily dose of either $1,25(\mathrm{OH})_{2} \mathrm{D}_{3}$ or EB1089. One group of tumor-bearing animals received vehicle alone as a control. Other control groups of sham-operated animals without tumor received either $1,25(\mathrm{OH})_{2} \mathrm{D}_{3}$, EB1089, or vehicle alone through osmotic minipumps as described above for up to $4 \mathrm{wk}$.

All animals were weighed every third day for up to $4 \mathrm{wk}$. Blood samples were collected every third day from each group under ether anesthesia and plasma samples were stored at $-20^{\circ} \mathrm{C}$ until the time of analysis. The tumor mass of control and experimental animals was measured in two dimensions by calipers and the tumor volume was calculated (18). Tumor tissue was also extracted for RNA analysis.

Analytical methods. Plasma calcium levels were determined by atomic-absorption spectrophotometry (model 703; Perkin-Elmer Corp., Norwalk, CT).

For RIA of PTHRP, rat plasma was tested in two dilutions in duplicate using an $\mathrm{NH}_{2}$-terminal RIA, as described previously (19), and values were assigned using a PTHRP(1-34) standard. Consequently, all values are in picomole equivalents per liter relative to PTHRP(134). These samples were also tested in an $\mathrm{NH}_{2}$-terminal RIA kit (Incstar Corporation, Stillwater, MN), according to manufacturer's instructions.

For Northern blot analysis, $20 \mu \mathrm{g}$ of total RNA was electrophoresed on a $1.1 \%$ agarose-formaldehyde gel and transferred by blotting to a nylon membrane (20). The filters were hybridized (21) with an EcoRI, Xbal restriction fragment of PTHRP cDNA M-9 and a rat cyclophylin 800-bp pair BamHI restriction fragment from plasmid pCD15.8.1 (6, 22). Each was labeled with $\left[{ }^{32} \mathrm{P}\right] \mathrm{dCTP}$ by the random primer method (23). After incubation at $42^{\circ} \mathrm{C}$ for $24 \mathrm{~h}$, filters were washed twice for 30 min each in $2 \times \mathrm{SSC}, 0.1 \% \mathrm{SDS}$ at $50^{\circ} \mathrm{C}(1 \times \mathrm{SSC}$ is $0.15 \mathrm{M}$ sodium chloride, $0.015 \mathrm{M}$ trisodium citrate). Autoradiography of filters was then carried out and the intensity of the autoradiograms was analyzed by laser densitometry (Ultroscan XL; LKB Instruments Inc., Gaithersburg, MD). The signals for PTHRP mRNA were related to that for cyclophilin mRNA, which was not changed by the various agents tested.

Statistical analysis. All results are expressed as the mean \pm SEM, and statistical comparisons are made on the basis of a Student's $t$ test or a one-way analysis of variance, using a Bonferroni adjustment where appropriate (24).

\section{Results}

\section{Effects on hypercalcemia}

Effect of $1,25(\mathrm{OH})_{2} \mathrm{D}_{3}$ and EB1089 on plasma calcium. In nontumor-bearing animals the lowest dose of $1,25(\mathrm{OH})_{2} \mathrm{D}_{3}(50$ pmol/24 h) did not produce significant hypercalcemia, however, higher doses produced a progressive increase in plasma calcium (Fig. 1, top). In contrast, non-tumor-bearing animals receiving up to $200 \mathrm{pmol} / 24 \mathrm{~h}$ of EB1089 did not show any

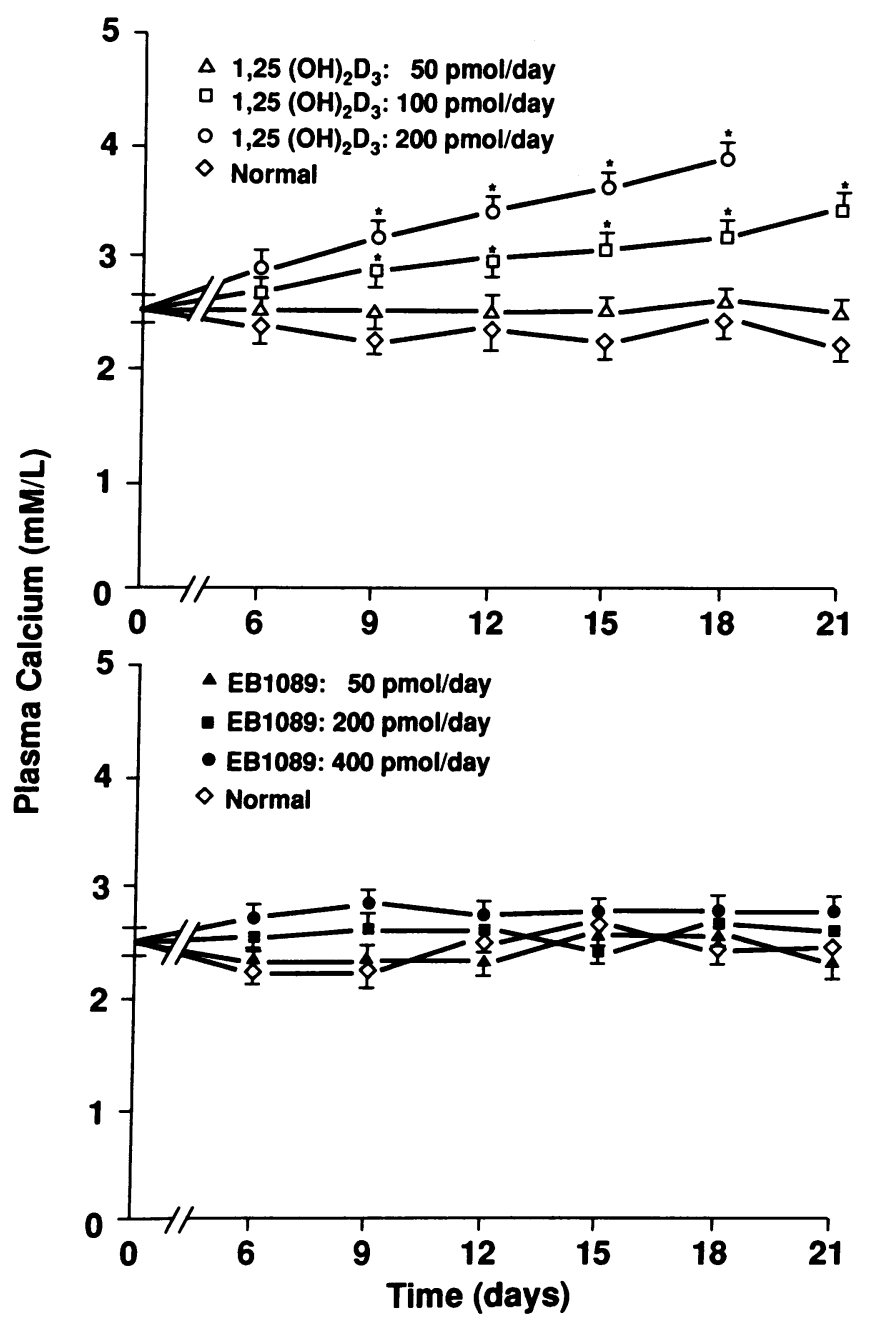

Figure 1. Effect of $1,25(\mathrm{OH})_{2} \mathrm{D}_{3}$ and EB1089 on plasma calcium in normal rats. Normal non-tumor-bearing male Fischer rats were infused with 50,100 , or $200 \mathrm{pmol} / 24 \mathrm{~h}$ of $1,25(\mathrm{OH})_{2} \mathrm{D}_{3}$ or with vehicle alone as described in Methods (top). Another group of animals were infused with 50,200 , or $400 \mathrm{pmol} / 24 \mathrm{~h}$ of EB1089 or vehicle alone (bottom). Animals were killed at timed intervals and their plasma calcium was determined as described in Methods. Results represent the mean \pm SEM of six starting animals in each group in four different experiments. Significant differences in plasma calcium from control non-tumor-bearing animals at each time point are represented by asterisks $\left({ }^{*} P<0.05\right)$.

significant increase in plasma calcium when compared to the vehicle-treated control group (Fig. 1, bottom).

Control vehicle-treated tumor-bearing animals showed a progressive increase in their plasma calcium starting 12-days after implantation (Fig. 2). The rise in plasma calcium was more pronounced in the tumor-bearing animals receiving 100 $\mathrm{pmol} / 24 \mathrm{~h}$ of $1,25(\mathrm{OH})_{2} \mathrm{D}_{3}$; those receiving $50 \mathrm{pmol} / 24 \mathrm{~h}$ of $1,25(\mathrm{OH})_{2} \mathrm{D}_{3}$ showed a significantly lower rise in plasma calcium as compared with the control animals (Fig. 2, top). Nevertheless, these animals did become hypercalcemic towards the end of experiment. In contrast, tumor-bearing animals infused with $\leq 200 \mathrm{pmol} / 24 \mathrm{~h}$ of the analogue maintained near-normal plasma levels comparable to the calcium levels of non-tumorbearing rats (Fig 2, bottom). This effect was sustained throughout the infusion of this vitamin D analogue (Fig. 2, bottom). 


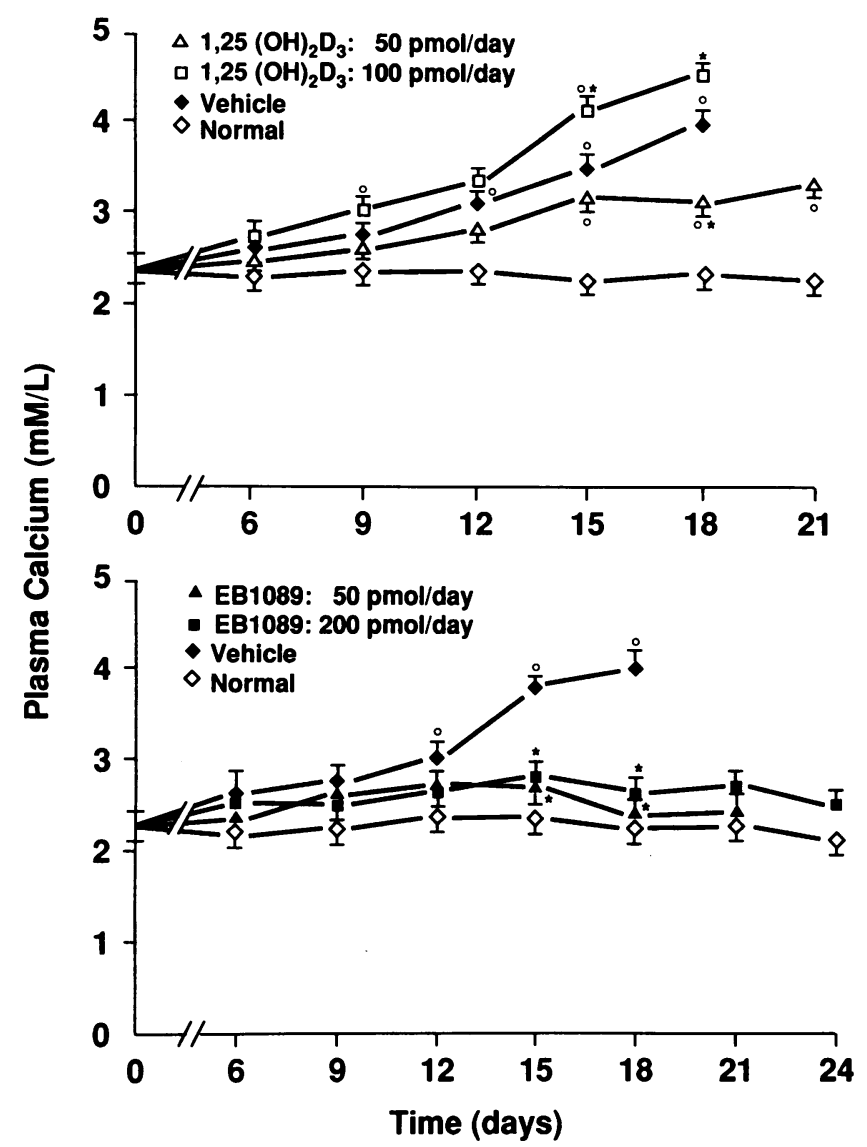

Figure 2. Effect of $1,25(\mathrm{OH})_{2} \mathrm{D}_{3}$ and EB1089 on plasma calcium in H-500 tumor-bearing rats. Tumor-bearing male Fischer rats were infused with 50 or $100 \mathrm{pmol} / 24 \mathrm{~h}$ of $1,25(\mathrm{OH})_{2} \mathrm{D}_{3}$, or with vehicle alone as described in Methods (top). Another group of animals was infused with 50 or $200 \mathrm{pmol} / 24 \mathrm{~h}$ of EB1089 or with vehicle alone (bottom). Animals were killed at timed intervals and their plasma calcium was determined as described in Methods. Plasma calcium in normal non-tumor-bearing animals is also shown. Results represent the mean \pm SEM of six starting animals in each group in four different experiments. Significant differences in plasma calcium from control tumor-bearing and normal non-tumor-bearing animals at each time point are represented by $*$ and $\circ$, respectively $(*, \circ P<0.05)$.

\section{Effects on tumor characteristics}

Effect on animal weight. Normal vehicle-treated rats without tumor implantation showed a progressive gain in weight during the study (Fig. 3). Animals receiving a low dose of 1,25 $(\mathrm{OH})_{2} \mathrm{D}_{3}$ also displayed a gain in body weight, however, the higher doses induced a drop in body weight (Fig. 3, top). In contrast all doses of EB1089 permitted a progressive gain in weight over time that was parallel to the vehicle-treated control group in these non-tumor-bearing rats (Fig. 3, bottom).

Tumor-bearing animals receiving vehicle alone progressively decreased their weight during the study, and at day 18 after tumor implantation, all animals in this group died (Fig. 4). Animals receiving $100 \mathrm{pmol} / 24 \mathrm{~h}$ of $1,25(\mathrm{OH})_{2} \mathrm{D}_{3}$ showed a more pronounced body weight decline than the control group, whereas the animals receiving $50 \mathrm{pmol} / 24 \mathrm{~h}$ of 1,25 $(\mathrm{OH})_{2} \mathrm{D}_{3}$ had a less dramatic drop in body weight, which was noticeable only by day 18 (Fig. 4, top). In contrast, all tumor- bearing animals receiving the different doses of EB1089 exhibited a gain in weight up to day 15 and then slowly decreased their weight. A more marked drop was observed with the lowest dose (50 pmol/24 h) of EB1089 (Fig. 4, bottom).

Effect on tumor volume. Tumor-bearing animals receiving vehicle alone showed a progressive increase in their tumor volume from day 12 until their death by day 18 (Fig. 5). Animals receiving $50 \mathrm{pmol} / 24 \mathrm{~h}$ of $1,25(\mathrm{OH})_{2} \mathrm{D}_{3}$ or $200 \mathrm{pmol} / 24 \mathrm{~h}$ of EB1089 showed no difference in their tumor volume up to day 15 compared with control tumor-bearing animals receiving vehicle alone. However, by day 18 after tumor implantation, the tumor volume of the animals treated with $1,25(\mathrm{OH})_{2} \mathrm{D}_{3}$ or EB1089 was significantly reduced. Furthermore, animals receiving these agents survived beyond day 18 and did not exhibit any further increase in their tumor volume (data not shown).

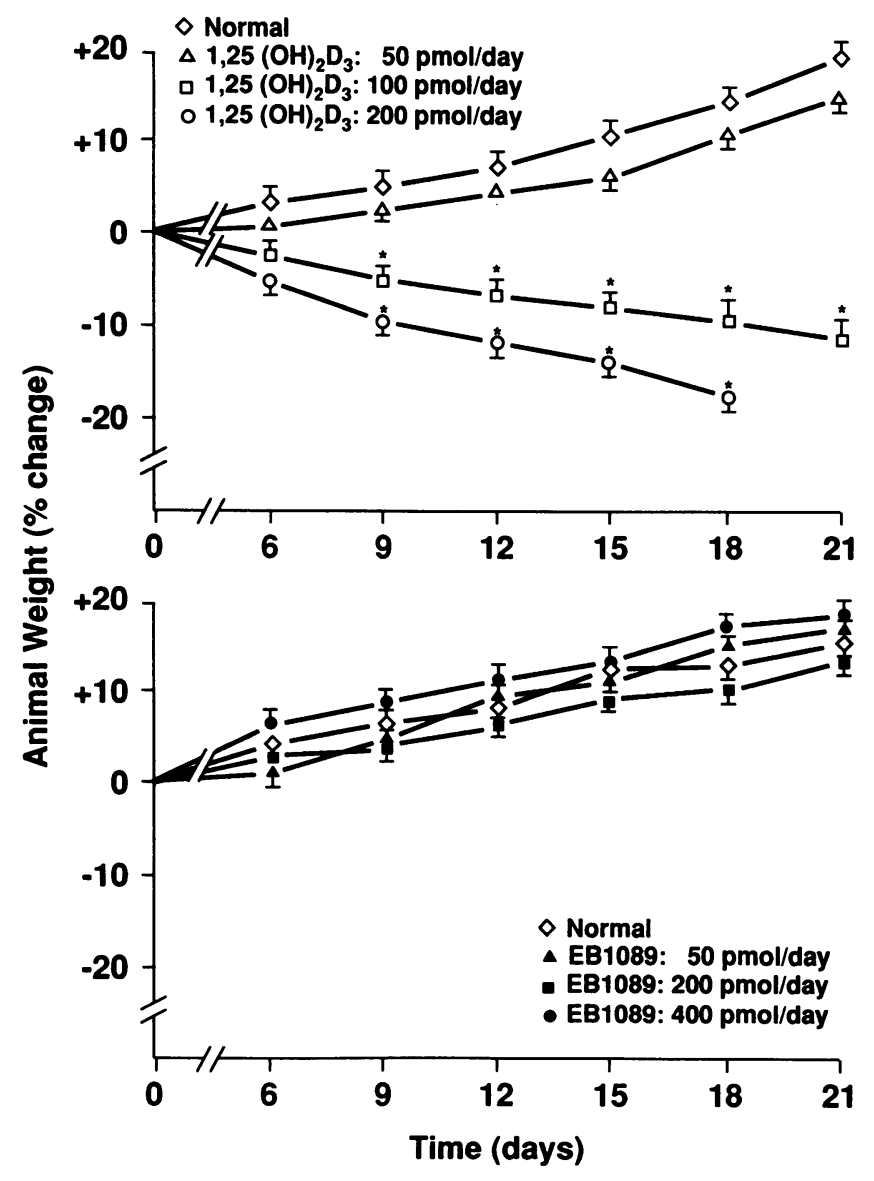

Figure 3. Effect of $1,25(\mathrm{OH})_{2} \mathrm{D}_{3}$ and $\mathrm{EB} 1089$ on body weight in normal animals. Normal non-tumor-bearing male Fischer rats were infused with 50,100 , or $200 \mathrm{pmol} / 24 \mathrm{~h}$ of $1,25(\mathrm{OH})_{2} \mathrm{D}_{3}$ or with vehicle alone as described in Methods (top). Another group of animals were infused with 50,200 , or $400 \mathrm{pmol} / 24 \mathrm{~h}$ of EB1089 or with vehicle alone (bottom). Animals were weighed at timed intervals and compared with their initial weight at the start of experiment. Results are expressed as percent change. Each time point represents the mean \pm SEM of six starting animals in each group in four different experiments. Significant differences in weight from control nontumor-bearing animals at each time point are represented by asterisks $\left({ }^{*} P<0.01\right)$. 


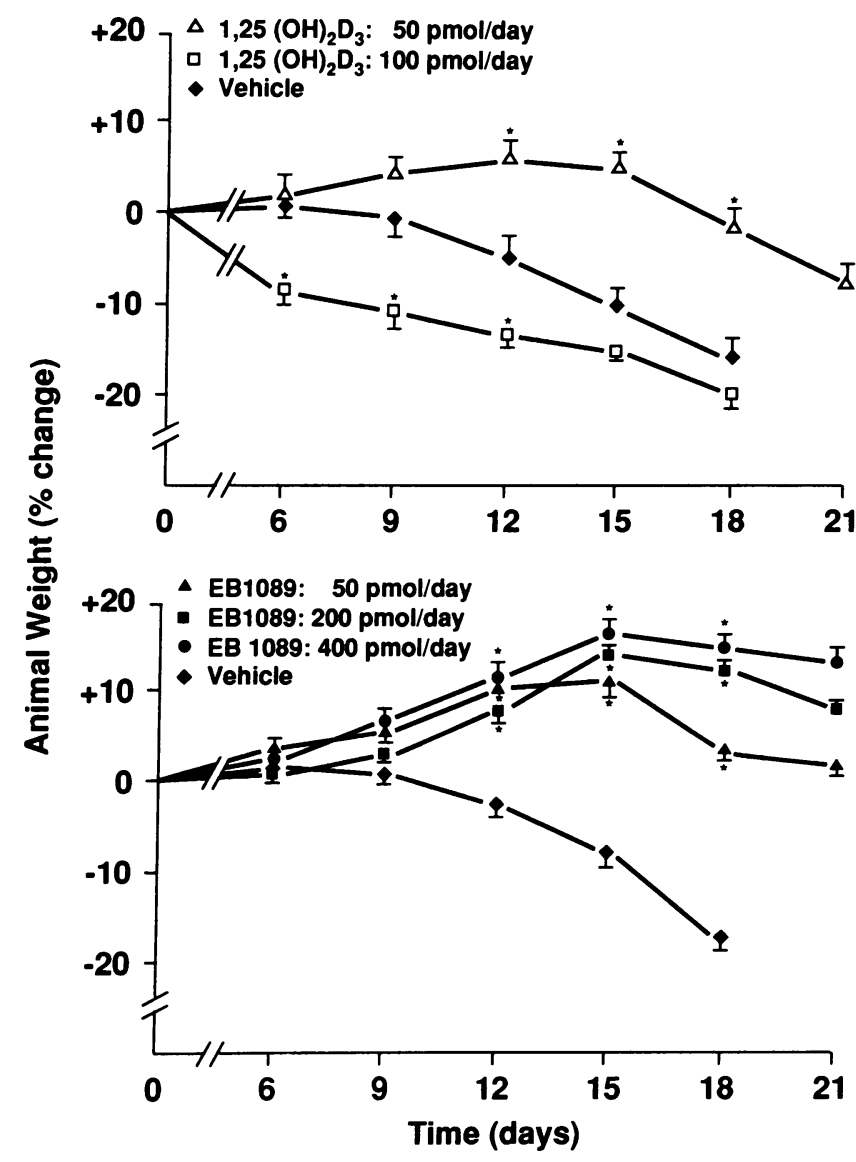

Figure 4. Effect of $1,25(\mathrm{OH})_{2} \mathrm{D}_{3}$ and EB1089 on body weight in H-500 tumor-bearing animals. Tumor-bearing male Fischer rats were infused with $50,100 \mathrm{pmol} / 24 \mathrm{~h}$ of $1,25(\mathrm{OH})_{2} \mathrm{D}_{3}$, or with vehicle alone as described in Methods (top). Another group of animals were infused with 50,200 , or $400 \mathrm{pmol} / 24 \mathrm{~h}$ of EB1089 or with vehicle alone (bottom). Animals were weighed at timed intervals and compared with their own initial weight at the start of experiment. Results are expressed as percentage change. Each time point represents the mean \pm SEM of six starting animals in each group in four different experiments. Significant differences in weight from control tumorbearing animals at each time point are represented by asterisks $\left({ }^{*} P\right.$ $<0.01)$.

Effects of $1,25(\mathrm{OH})_{2} \mathrm{D}_{3}$ and EB1089 on PTHRP production. PTHRP mRNA from the tumors of implanted animals was measured at timed intervals (days 12,15, and 18). Tumor PTHRP mRNA increased over time in the animals receiving vehicle alone (Fig. 6). Animals receiving either $1,25(\mathrm{OH})_{2} \mathrm{D}_{3}$ $(50 \mathrm{pmol} / 24 \mathrm{~h})$ or its analogue EB1089 $(200 \mathrm{pmol} / 24 \mathrm{~h}) \mathrm{dem}$ onstrated a dramatic decrease in PTHRP mRNA expression in tumor tissue compared with the vehicle-treated control group (Fig. 6). Similar results were seen with $100 \mathrm{pmol} / 24 \mathrm{~h}$ of $1,25(\mathrm{OH})_{2} \mathrm{D}_{3}$.

Immunoreactive PTHRP (iPTHRP) was undetectable in non-tumor-bearing animals. However, all tumor-bearing animals had detectable concentrations of plasma iPTHRP as of 12 $\mathrm{d}$ after tumor implantation and the levels progressively increased (Fig. 7). Comparison of PTHRP immunoreactivity at days 12,15 , and 18 among the various treatment groups re-

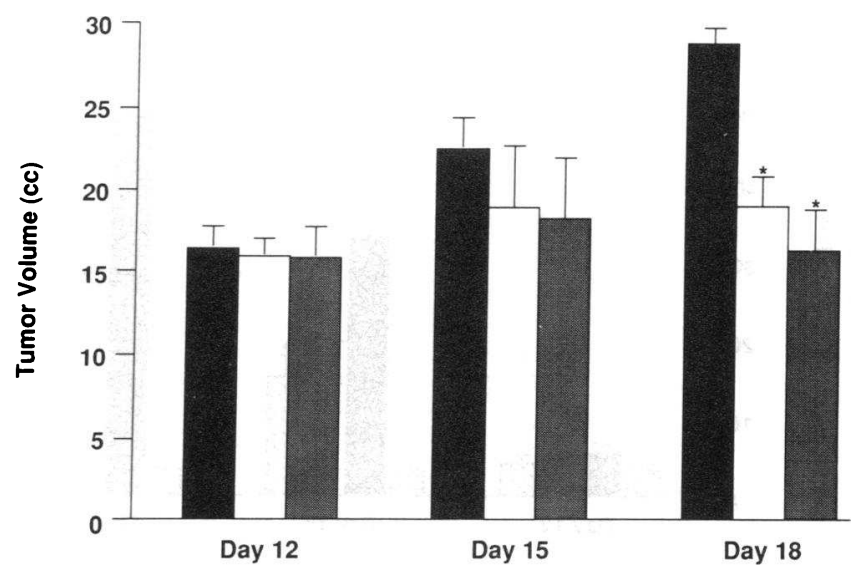

Figure 5. Effect of $1,25(\mathrm{OH})_{2} \mathrm{D}_{3}$ and EB1089 on tumor volume. Tumor volume was determined at timed intervals as described in Methods. Tumor volume after treatment of animals with $50 \mathrm{pmol} / 24 \mathrm{~h}$ $1,25(\mathrm{OH})_{2} \mathrm{D}_{3}$ (口) or $200 \mathrm{pmol} / 24 \mathrm{~h}$ EB1089 (匹) was compared with the volume of tumors in animals receiving the vehicle alone ( $(\mathbf{)})$. Results represent the mean \pm SEM of six starting animals in each group in four different experiments. Significant differences from control tumor-bearing animals at each time point are represented by asterisks $\left({ }^{*} P<0.05\right)$.

vealed a decrease in iPTHRP concentrations in animals receiving either $1,25(\mathrm{OH})_{2} \mathrm{D}_{3}$ or its analogue EB1089 compared with the tumor-bearing animals receiving vehicle alone (Fig. 7).
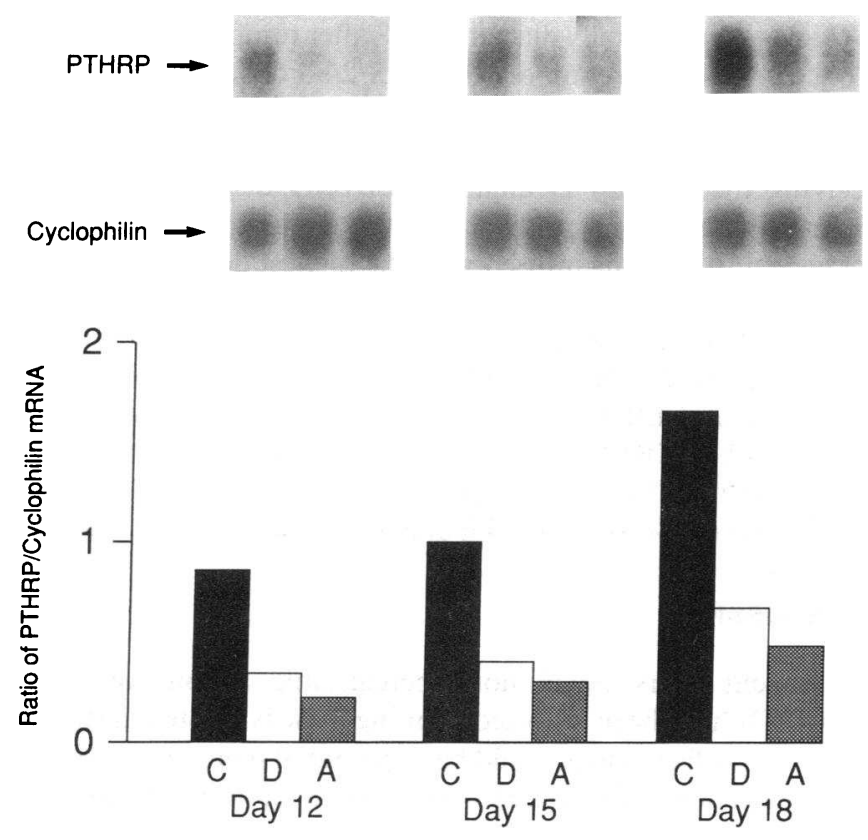

Figure 6. Effect of $1,25(\mathrm{OH})_{2} \mathrm{D}_{3}$ and EB1089 on PTHRP mRNA expression in H-500 tumors. PTHRP mRNA expression was determined in tumor extracts, as described in Methods, at timed intervals after the onset of tumor growth. PTHRP mRNA expression (top) after treatment of animals with $50 \mathrm{pmol} / 24 \mathrm{~h} 1,25(\mathrm{OH})_{2} \mathrm{D}_{3}(D)$ or 200 $\mathrm{pmol} / 24 \mathrm{~h}$ of the analogue EB1089 $(A)$ was compared with PTHRP mRNA expression in control tumors from animals receiving the vehicle alone $(C)$. All blots were quantified by probing with cyclophylin as a control (bottom). Ratios of PTHRP/cyclophylin mRNA are shown in the figure below the panels. 


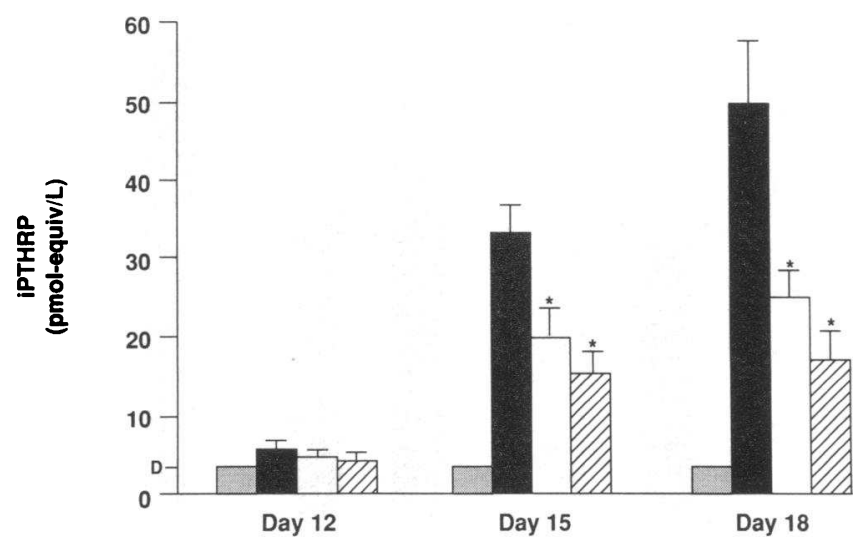

Figure 7. Effect of $1,25(\mathrm{OH})_{2} \mathrm{D}_{3}$ and EB1089 on plasma iPTHRP concentrations in H-500 tumor-bearing animals. PTHRP concentrations were determined as described in Methods at timed intervals. PTHRP concentrations were examined in non-tumor-bearing animals receiving vehicle alone ( $\square$ ) and in $\mathrm{H}-500$ tumor-bearing animals receiving vehicle alone $(\square), 50 \mathrm{pmol} / 24 \mathrm{~h}$ of $1,25(\mathrm{OH})_{2} \mathrm{D}_{3}(\square)$ or 200 $\mathrm{pmol} / 24 \mathrm{~h}$ of EB1089 (四). $D$ represents the detection limit of the assay. Results represent the mean \pm SEM of six starting animals in each group in four different experiments. Significant differences from control tumor-bearing animals at each time point are represented by asterisks $\left({ }^{*} P<0.01\right)$.

Effect of EB1089 on survival time. We next assessed the effect of either $1,25(\mathrm{OH})_{2} \mathrm{D}_{3}$ or its analogue EB1089 on survival time of the tumor-bearing animals. Animals receiving vehicle alone generally died at day 18 after tumor implantation (Fig. 8). Administration of $100 \mathrm{pmol} / 24 \mathrm{~h}$ of $1,25(\mathrm{OH})_{2} \mathrm{D}_{3}$ reduced the survival time whereas $50 \mathrm{pmol} / 24 \mathrm{~h}$ of $1,25(\mathrm{OH})_{2} \mathrm{D}_{3}$ produced a modest increase in survival. However, animals receiving the vitamin D analogue EB1089 displayed a more marked increase in survival time with the longest survival achieved in animals infused with the highest dose $(400 \mathrm{pmol} /$ $24 \mathrm{~h}$ ) of EB1089. By day 20 after tumor implantation, few of the animals receiving the low dose of $1,25(\mathrm{OH})_{2} \mathrm{D}_{3}(50 \mathrm{pmol} /$ $24 \mathrm{~h}$ ) survived whereas $100 \%$ of the animals receiving 400 pmol/24 h of EB 1089 and $84 \%$ of the animals receiving 200 $\mathrm{pmol} / 24 \mathrm{~h}$ of EB 1089 survived. By day 24, at which time none of the animals in the other groups were alive, $67 \%$ of the animals receiving $400 \mathrm{pmol} / 24 \mathrm{~h}$ of EB 1089 had survived (Fig. 8).

\section{Discussion}

In recent years novel nonhypercalcemic actions of 1,25$(\mathrm{OH})_{2} \mathrm{D}_{3}$ have been reported. Among these is a potent antiproliferative effect, which could be of potential therapeutic benefit in cancer states (25-27). However, the inherent hypercalcemic activity of $1,25(\mathrm{OH})_{2} \mathrm{D}_{3}$ has prevented its use as a potential therapeutic agent in this regard. Recently, intense efforts have resulted in the development of several $1,25(\mathrm{OH})_{2} \mathrm{D}_{3}$ analogues that exhibit low calcemic activity. The major modifications of $1,25(\mathrm{OH})_{2} \mathrm{D}_{3}$ that have resulted in low calcemic analogues have been structural changes in the side chain, such as introduction of oxygen atoms and stereochemical changes (27-29). We have used one such analogue, EB1089, in our studies. In this analogue the side chain has been elongated with introduction of terminal ethyl groups and double bonds have been intro- duced at positions 22 and 24 (16). Low calcemic analogues of vitamin $D$ retain the antiproliferative effects of $1,25(\mathrm{OH})_{2} \mathrm{D}_{3}$ but are far less active in absorption of intestinal calcium and mobilization of calcium from bone (28). Indeed EB1089 has previously been reported to be $\sim 60$ times more active in inhibiting cell proliferation and inducing cell differentiation than $1,25(\mathrm{OH})_{2} \mathrm{D}_{3}$ in $\mathrm{U} 937$ histiocytic lymphoma cells in vitro while having a threefold lower calciuric activity in normal rats in vivo (30). In addition, in common with $1,25(\mathrm{OH})_{2} \mathrm{D}_{3}$, several of the low calcemic analogues may decrease the synthesis of parathyroid hormone, induce osteocalcin gene expression in bone cells, inhibit angiogenesis, and display immunoregulatory activity $(29,31-33)$. Administration of such $1,25(\mathrm{OH})_{2} \mathrm{D}_{3}$ analogues either orally, intraperitoneally, or by direct injection into tumor tissue has been shown in certain models to decrease tumor volume and prolong animal survival without causing hypercalcemia $(27,28,34)$.

We compared the capacity of $1,25(\mathrm{OH})_{2} \mathrm{D}_{3}$ and of EB 1089 to control the syndrome of malignancy-associated hypercalcemia in vivo. The rationale of this approach was primarily made on the basis of our previous demonstration that both $1,25(\mathrm{OH})_{2} \mathrm{D}_{3}$ and calcipotriol, an analogue of $1,25(\mathrm{OH})_{2} \mathrm{D}_{3}$ with only low calcemic potency, could effectively inhibit PTHRP gene expression and PTHRP secretion from cells maintained in culture (35). Thus, the combination of the known antiproliferative actions of vitamin $\mathrm{D}$ and its analogues and its potent action on inhibiting PTHRP production suggested that it might be successfully employed in controlling malignancy-associated hypercalcemia in vivo. In view of the fact that calcipotriol did not appear to be a likely candidate for these studies because of its very short half-life, we used EB 1089, which has recently been reported to have approximately the same half-life in vivo as $1,25(\mathrm{OH})_{2} \mathrm{D}_{3}(30)$.

In our studies EB1089 failed to significantly raise plasma calcium concentrations above normal at doses as high as eight times the highest dose of $1,25(\mathrm{OH})_{2} \mathrm{D}_{3}(50 \mathrm{pmol} / 24 \mathrm{~h})$, which produced only mild hypercalcemia. Non-tumor-bearing animals remained healthy and indistinguishable from animals in-

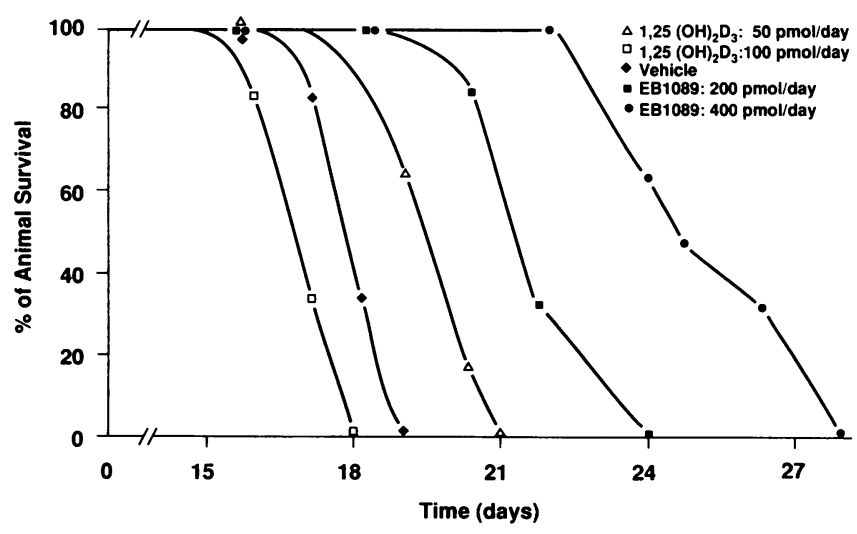

Figure 8. Effect of $1,25(\mathrm{OH})_{2} \mathrm{D}_{3}$ and EB1089 on animal survival time. The number of surviving tumor-bearing animals was assessed after infusion with vehicle alone, with $1,25(\mathrm{OH})_{2} \mathrm{D}_{3}$ at a dose of 50 or 100 $\mathrm{pmol} / 24 \mathrm{~h}$, or with EB1089 at a dose of $200 \mathrm{pmol} / 24 \mathrm{~h}$ or $400 \mathrm{pmol} /$ $24 \mathrm{~h}$. Each group consisted of six animals and percentage survival at each time point was calculated. 
fused with vehicle alone for the duration of the experiment. These results predicted that EB 1089 could be used safely in the cancer state and could be used at substantially higher doses than $1,25(\mathrm{OH})_{2} \mathrm{D}_{3}$ to enhance its potential antitumor effects in our model. Administration of the analogue to tumor-bearing animals, even in the lowest dose used, was effective in preventing overt hypercalcemia. The lowest dose of $1,25(\mathrm{OH})_{2} \mathrm{D}_{3}$ used was almost as effective, but doubling of this dose, and further increases, resulted in rapidly progressing hypercalcemia and death of the animals. This hypercalcemia occurred despite inhibition of PTHRP production, indicating that this was due to the intrinsic actions of $1,25(\mathrm{OH})_{2} \mathrm{D}_{3}$. In previous studies it has been reported that infusions of $7 \mathrm{pmol} / 24 \mathrm{~h}$ of $1,25(\mathrm{OH})_{2} \mathrm{D}_{3}$ are required to restore normocalcemia and normal plasma $1,25(\mathrm{OH})_{2} \mathrm{D}_{3}$ concentrations in hypocalcemic vitamin $\mathrm{D}$-depleted rats (36). In our study normal animals received Leydig cell tumor implants and in these animals normal plasma concentrations of $1,25(\mathrm{OH})_{2} \mathrm{D}_{3}$ were incapable of inhibiting PTHRP production or hypercalcemia. Consequently, it appears likely that only infusions between 7 and $50 \mathrm{pmol} / 24 \mathrm{~h}$ of $1,25(\mathrm{OH})_{2} \mathrm{D}_{3}$ would be effective in reducing tumor induced hypercalcemia. Whether the therapeutic window of 1,25$(\mathrm{OH})_{2} \mathrm{D}_{3}$ is significantly smaller than that of the analogue EB1089 or of newer generations of such analogues will require further study but $1,25(\mathrm{OH})_{2} \mathrm{D}_{3}$ and EB1089 are clearly both effective in vivo.

Analysis of PTHRP mRNA levels in the tumor confirmed our hypothesis that $1,25(\mathrm{OH})_{2} \mathrm{D}_{3}$ and its analogue could inhibit PTHRP gene expression in vivo as well as in vitro. This inhibition was unlikely to be simply due to the antiproliferative effects of these agents, inasmuch as mRNA encoding PTHRP was selectively reduced relative to cyclophylin mRNA. In vitro, at least part of the inhibitory effect of vitamin $D$ appears to be at the level of PTHRP gene transcription (11). Whether similar molecular mechanisms are involved in the in vivo inhibitory actions of vitamin $\mathrm{D}$ and its analogue remains to be determined. Circulating levels of iPTHRP were also diminished by $1,25(\mathrm{OH})_{2} \mathrm{D}_{3}$ and its analogue in keeping with its inhibitory effect on PTHRP secretion in vitro. Although iPTHRP concentrations were reduced as compared with control tumor-bearing animals, they were not completely suppressed. This nonsuppressible immunoreactivity may represent biologically inert $\mathrm{NH}_{2}$-terminal material or may represent a level of biologically active PTHRP whose hypercalcemic activity may be neutralized by compensatory mechanisms. An analogous situation has been reported in humans with tumors in which elevated circulating concentrations of PTHRP have been described in association with normocalcemia $(19,37,38)$.

We have also examined beneficial antineoplastic properties of $1,25(\mathrm{OH})_{2} \mathrm{D}_{3}$ and EB1089 other than inhibition of PTHRP production. A reduction in tumor volume was observed with both the lowest dose of $1,25(\mathrm{OH})_{2} \mathrm{D}_{3}$ used as well as with the higher dose of analogue used. Such a reduction may well have been due to the antiproliferative activity of both vitamin $\mathrm{D}$ and its analogue. However, even in the absence of severe hypercalcemia, the low dose of $1,25(\mathrm{OH})_{2} \mathrm{D}_{3}$ was unable to prevent weight loss after day 12 and survival time was markedly lower than with the higher concentrations of analogue that could be used. These results suggest that the analogue may have additional properties at the concentration used, such as the inhibition of other tumor products that contribute to cachexia and death. Further studies will be required to evaluate these possibilities.

\section{Acknowledgments}

We thank Dr. Lise Binderup for providing EB1089 and for helpful discussions, Ms. Julie Gladu for technical assistance, and Ms. Karuna Patel and Ms. Shelley Hall for preparation of the manuscript.

This work was supported by the Medical Research Council (MRC) of Canada Grants MT-10630, MT-10839, and MT-5775 and by the National Cancer Institute of Canada. S.A. Rabbani is a recipient of a scholarship from MRC of Canada and from the Cancer Research Society.

\section{References}

1. Moseley, J. M., M. Kubota, H. D. Diefenbach-Jagger, R. E. H. Wettenhall, B. E. Kemp, L. J. Suva, C. P. Rodda, P. R. Ebeling, P. J. Hudson, J. D. Zajac, et al. 1987. Parathyroid hormone-related protein purified from a human lung cancer cell line. Proc. Natl. Acad. Sci. USA. 84:5048-5052.

2. Stewart, A. F., T. Wu, D. Goumas, W. J. Burtis, and A. E. Broadus. 1987 $\mathrm{N}$-terminal amino acid sequence of two novel tumor-derived adenylate cyclasestimulating proteins: identification of parathyroid hormone-like and parathyroid hormone-unlike domains. Biochem. Biophys. Res. Commun. 146:672-678.

3. Strewler, G. J., P. H. Stern, J. W. Jacobs, J. Eveloff, R. F. Klein, S. C. Leung, M. Rosenblatt, and R. A. Nissenson. 1987. Parathyroid hormonelike protein from human renal carcinoma cells. Structural and functional homology with parathyroid hormone. J. Clin. Invest. 80:1803-1807.

4. Suva, L. J., G. A. A. Winslow, R. E. H. Wettenhall, R. G. Hammonds, J. M. Moseley, H. Diefenbach-Jagger, C. P. Rodda, B. E. Kemp, H. Rodriguez, E. Y. Chen, et al. 1987. A parathyroid hormone-related protein implicated in malignant hypercalcemia: cloning and expression. Science (Wash. DC). 237:893-896.

5. Mangin, M., A. C. Webb, B. E. Dreyer, J. T. Posillico, K. Ikeda, E. C. Weir, A. F. Stewart, N. H. Bander, L. Milstone, D. E. Barton, et al. 1988. Identification of a cDNA encoding a parathyroid hormone-like peptide from a human tumor associated with humoral hypercalcemia of malignancy. Proc. Natl. Acad. Sci. USA. 85:597-6017.

6. Yasuda, T., D. Banville, S. A. Rabbani, G. N. Hendy, and D. Goltzman. 1989. Rat parathyroid hormone-like peptide: comparison with the human homologue and expression in malignant and normal tissue. Mol. Endocrinol. 3:518525 .

7. Sica, D. A, R. R. Martodam, J. Aronow, and G. R. Mundy. 1983. The hypercalcemic rat Leydig cell tumor-a model of the humoral hypercalcemia of malignancy. Calcif. Tissue Int. 35:287-293.

8. Insogna, K. L., A. F. Stewart, A. M. Vignery, E. C. Weir, P. A. Namnum, R. E. Baron, J. M. Kirkwood, L. M. Deftos, and A. E. Broadus, 1984. Biochemical and histomorphometric characterization of a rat model for humoral hypercalcemia of malignancy. Endocrinology. 114:888-896.

9. Rabbani, S. A., J. Mitchell, D. R. Roy, R. Kremer, H. P. J. Bennett, and D. Goltzman. 1986. Purification of peptides with parathyroid hormone-like bioactivity from human and rat malignancies associated with hypercalcemia. Endocrinology. 118:1200-1210.

10. Gaich, G., and W. J. Burtis. 1990. Measurement of circulating parathyroid hormone-related protein in rats with humoral hypercalcemia of malignancy using a two-site immunoradiometric assay. Endocrinology. 127:1444-1449.

11. Kremer, R., A. C. Karaplis, J. Henderson, W. Gulliver, D. Banville, G. N. Hendy, and D. Goltzman. 1991. Regulation of parathyroid hormone-like peptide in cultured normal human keratinocytes. J. Clin. Invest. 87:884-893.

12. Ikeda, K., C. Lu, E. C. Weir, M. Mangin, and A. E. Broadus. 1989. Transcriptional regulation of parathyroid hormone-related peptide gene by glucocorticoid and vitamin D in a human C-cell line. J. Biol. Chem. 264:1574315746.

13. Liu, B., D. Goltzman, and S. A. Rabbani. 1993. Regulation of parathyroid hormone-related peptide production in vitro by the rat hypercalcemic Leydia cell tumor H-500. Endocrimology. 132:1658-1664.

14. Henderson, L., M. Sebag, J. Rhim, D. Goltzman, and R. Kremer. 1991. Dysregulation of parathyroid hormone-like peptide expression and secretion in a keratinocyte model of tumor progression. Cancer Res. 51:6521-6528.

15. Binderup, E., M. J., Calverley, and L. Binderup. 1991. Synthesis and biological activity of alpha-hydroxylated vitamin $\mathrm{D}$ analogues with poly-unsaturated side chains, In Vitamin D: Gene Regulation, Structure-Function Analysis and Clinical Application: Proceedings of the 8th Workshop on Vitamin D. July 5-10, 1991, Paris. A. W. Norman, R. Bouillon, and M. Thomasset, editors. de Gruyter, Berlin. 192-193.

16. Henderson, J., S. Bernier, P. D'Amour, and D. Goltzman. 1990. Effects of passive immunization against parathyroid hormone (PTH)-like peptide and PTH 
in hypercalcemic tumor-bearing rats and normocalcemic controls. Endocrinology. 127:1310-1318.

17. Holloran, B. P., D. D. Bikle, M. J. Levens, M. E. Castro, R. K. Globus, and E. Holton. 1986. Chronic 1,25-dihydroxyvitamin $D_{2}$ administration in the rat reduces the serum concentration of 25 -hydroxyvitamin $\mathrm{D}$ by increasing metabolic clearance rate. J. Clin. Invest. 78:622-628.

18. Steiner, M. S., and E. R. Barrack. 1990. Expression of transforming growth factors and epidermal growth factor in normal and malignant rat prostate. J. Urol. 143:240A. (Abstr.)

19. Henderson, J., C. Shustik, R. Kremer, S. A. Rabbani, G. N. Hendy, and D. Goltzman. 1989. Circulating concentrations of parathyroid hormone-like peptide in malignancy and in hyperparathyroidism. J. Bone Miner. Res. 5:105-113.

20. Gilsin, V., R. Crkvenjakov, and C. Byus. 1974. Ribonucleic acid isolated by cesium chloride centrifugation. Biochemistry. 13:2633-2637.

21. Thomas, P. S. 1980 . Hybridization of denatured RNA and small DNA fragments transferred to nitrocellulose. Proc. Natl. Acad. Sci. USA. 77:52015205 .

22. Danielson P. E., S. Forss-Petter, M. A. Brow, L. Calaretta, J. Douglass, R. J. Milner, and J. G. Sutcliffe. 1988. p1B15: a cDNA clone of the rat mRNA encoding cyclophilin. DNA (NY). 7:261-267.

23. Feinberg A. P., and P. Vogelstein. 1983. A technique for radiolabeling DNA restriction endonuclease fragments to high specific activity. Anal. Biochem. 137:266-267.

24. Glantz, S. A. 1981. Primer of Biostastics. McGraw Hill, New York.

25. Frampton, R. J., S. A. Omond, J. A. Eisman. 1983. Inhibition of human cancer cell growth by 1,25-dihydroxyvitamin $D_{3}$ metabolites. Cancer Res. 43:4443-4447.

26. Eisman, J. A., D. H. Barkla, and P. J. M. Tutton. 1987. Suppression of in vivo growth of human cancer solid tumor xenografts by 1,25-dihydroxyvitamin $D_{3}$. Cancer Res. 47:21-25.

27. Honma, T., M. Hozumi, E. Abe, K. Konno, M. Fukushima, S. Hata, Y. Nishii, H. F. DeLuca, and T. Suda. 1983. $1 \alpha, 25$-dihydroxyvitamin $\mathrm{D}_{3}$ and $1 \alpha$-hydroxyvitamin $\mathrm{D}_{3}$ prolong survival time of mice inoculated with myeloid leukemia cells. Proc. Natl. Acad. Sci. USA. 80:201-204.

28. Zhou, J. Y., A. W. Norman, D. L. Chen, G. W. Sun, M. Uskokovic, and H. P. Koeffler. 1990. 1,25-Dihydroxy-16-ene-23-yne-vitamin $D_{3}$ prolongs survival time of leukemic mice. Proc. Natl. Acad. Sci. USA. 87:3929-3932.

29. Brown, A. J., C. R. Ritter, J. L. Finch, J. Morrissey, K. J. Martin, E. Murayama, Y. Nishii, and E. Slatopolsky. 1989. The noncalcemic analogue of vitamin D, 22-oxacalcitriol, suppresses parathyroid hormone synthesis and secretion. J. Clin. Invest. 84:728-732.

30. Binderup, L., S., Latini, and A. M. Kissmayer. 1991. New vitamin $D_{3}$ analogues with potent effects on cell growth and clinical. In Vitamin D: Gene Regulation, Structure-Function Analysis and Clinical Application: Proceedings of the 8th Workshop on Vitamin D. July 5-10, 1991, Paris. A. W. Norman, R. Bouillon, and M. Thomasset, editors. de Gruyter, Berlin. 478-485.

31. Morrison, N. A., and J. A. Eisman. 1990. Non-hypercalcemic analogs of 1,25-dihydroxyvitamin $\mathrm{D}_{3}$ fully induce the human osteocalcin gene promoter in stably transfected rat osteosarcoma cells (ROSCO-2). J. Bone Miner. Res. 5:A278, S-143.

32. Oikawa T., K. Hirotani, H. Ogasawara, T. Katayama, O. Nakamura, T. Iwaguchi, and A. Hiragun. 1990. Inhibition of angiogenisis by vitamin $D_{3}$ analogues. Eur. J. Pharmacol. 178:247-250.

33. Abe, J., Y. Takita, T. Nakano, C. Miyaura, T. Suda, and Y. Nishii. 1989. A synthetic analogue of vitamin $D_{3}, 22$-oxa-1,25-dihydroxyvitamin $D_{3}$, is a potent modulator of in vivo immunoregulating activity without inducing hypercalcemia in mice. Endocrinology. 124:2645-2647.

34. Abe, J., T. Nakano, Y. Nishii, T. Matsumoto, E. Ogata, and K.Ikeda 1991. A novel vitamin $D_{3}$ analog, 22-oxa-1,25-dihydroxyvitamin $D_{3}$, inhibits the growth of human breast cancer in vitro and in vivo without causing hypercalcemia. Endocrinologv. 129:832-837.

35. Kremer, R., V. Papavasiliou, J. Henderson, J. Rhim, and D. Goltzman 1991. Calcipotriol (MC903) is a potent inhibitor of parathyroid hormone-like peptide (PLP) expression in human keratinocytes. J. Bone Miner. Res. 6:A830, S-291.

36. Haddad, P., M. Gascon-Barré, G. Brault, and V. Plourde. 1986. Influence of calcium on 1,25-dihydroxyvitamin $\mathrm{D}_{3}$ supplementation on the hepatic microsomal and in vivo metabolism of vitamin $\mathrm{D}_{3}$ in vitamin $\mathrm{D}$-repleted rats. J. Clin. Invest. 78:1529-1537.

37. Budayr, A. A., R. A. Nissenson, R. F., Klein, K. K., Pun, O. H., Clark, D. Diep, C. D., Arnaud, and G. J., Strewler. 1989. Increased serum levels of a parathyroid hormone-like protein in malignancy-associated hypercalcemia. Ann. Intern. Med. 111:807-812.

38. Burtis, W. J., T. G., Brady, J. J., Orloff, J. B., Ersbak, R. P., Warrell, Jr., B. R., Olson, T. L., Wu, M. E., Mitnick, A. E., Broadus, and A. F., Stewart. 1990 Immunochemical characterization of circulating parathyroid hormone-related protein in patients with humoral hypercalcemia of cancer. N. Engl. J. Med. 332:1106-1112. 